\title{
Views of Physical Education Teachers on Distance Education During the Covid-19 Pandemic Period: A Qualitative Study
}

\author{
Hande Baba Kaya ${ }^{1}$ \\ ${ }^{1}$ Sports Science Faculty, Düzce University, Düzce, Turkey \\ Correspondence: Hande Baba Kaya, Sports Science Faculty, Düzce University, 81620 Yörük/Düzce, Turkey.
}

Received: April 9, 2021

doi:10.5539/ies.v14n9p77
Accepted: May 17, $2021 \quad$ Online Published: August 28, 2021

URL: https://doi.org/10.5539/ies.v14n9p77

\begin{abstract}
This study was carried out in order to examine the opinions of physical education teachers about the remote (online) education of schools due to the Covid-19 epidemic in our country and in the world in recent years, and the remote teaching of physical education lessons in this process. Within the scope of this study, it was tried to determine the opinions of physical education teachers about the distance education process, the problems they encountered, the efficiency and adequacy of the lessons, the advantages and disadvantages of the process. The study was designed using a qualitative research method, and the study group was determined using the stratified sampling method. Study data were collected by the researcher by interview method. The analysis of the data was carried out using the content analysis method. According to the findings of the research, in the evaluations of the participants; It has been observed that the majority of them define distance education as virtual education, the majority of them express that it is important and necessary to teach physical education lessons in distance education, the biggest advantage in the process of teaching the lessons is the lack of time and space limit, and the disadvantage is that distance education cannot provide the same equality of opportunity for every student. At the end of the study, suggestions were given to make physical education lessons more efficient in the distance education process.
\end{abstract}

Keywords: covid-19, distance education, physical education, pandemic

\section{Introduction}

The Covid -19 outbreak, which was declared as a pandemic by the world health organization, first appeared in Wuhan, China in November 2019. This epidemic, which started to spread rapidly within a short time of its emergence (WHO, 2020), affected the whole world in a short time. Due to the Covid-19 virus, which continues to spread rapidly despite the past year (Yip \& Chau, 2020), many health authorities have gathered within the framework of a consensus that it is important to maintain physical distance between people to prevent the spread of the virüs (Hellewell et al., 2020). Of course, educational institutions have been the most affected by this situation. 1.57 billion students enrolled in the education system in the world; It has been the group most affected by the temporary closure of educational institutions by many governments to prevent the spread of the pandemic (UNESCO, 2020a). It is not known when the process will end because the opening of schools is related to the effects of the pandemic and the virus continues to mutate and spread. However, the literature also emphasizes how important continuity is in teaching activities (UNESCO, 2020b, 2020c).

Immediately after they exit the first cases in Turkey were suspended training at all educational levels. In order to prevent the spread of the epidemic due to the continuation of the pandemic; With the decision of the Ministry of National Education (MEB) and the Higher Education Institution (YÖK), it has been decided to continue education remotely. Education application form in this process only take education to many countries face altered in many countries, not only in Turkey and has continued to distance learning (Al Lily et al., 2020). Distance education process; In Turkey, the Ministry of Education (MEB, 2020) supported a three television channels and EBA (Education Information Network) has started to be maintained to cover students at all school levels out. In this way, the courses conducted on EBA (Education Informatics Network) were provided through the internet, TRT channel and television, and the TV and internet-based distance education platforms were actively used (Özdoğan $\&$ Berkant, 2020). These lessons, which are very important for the physical, mental and mental development of children in face-to-face education, have been included in the distance education process and included in the process with exercise content that they can do at home and exercise hours created through the EBA (Education 
Information Network). Physical education lessons, which are not every day of the week in face-to-face education, continue to be taught with live lessons created over EBA during normal class hours during the distance education process. When we look at the definitions of distance education, we can define teaching as an independent environment where teachers and students in different times and places meet through information technologies and teaching using appropriate materials and documents (Uşun, 2006). In distance education applications, lessons can be conducted in two different ways. These; Students and teachers meet online at a previously determined common time (simultaneously) (Fidalgo et al., 2020) or in cases where it is not possible to meet in a common time period, teachers' pre-prepared lecture presentations, videos, etc., lesson materials. It is the type of asynchronous education that it shares, where students can access these contents at any time (Watts, 2016).

In order to realize this type of education, it is seen that different strategies, methods and techniques should be replaced with different requirements in terms of teachers, students and curricula, and to increase learning instead of standard teaching methods (Özcan \& Saraç, 2020). With the appearance of an unexpected pandemic, teachers who were unprepared in this regard suddenly had to teach lessons remotely and online. In this case, unlike face-to-face training, requirements such as using technology, managing the distance communication process well, developing digital learning resources, producing content that facilitates and supports learning have emerged (Ally, 2019; Bawane \& Spector, 2009; Farmer \& Ramsdale, 2016). Within the scope of this study, it was tried to examine how this process passed through the eyes of teachers, and the opinions of physical education teachers about the advantages and disadvantages of distance education were examined.

\section{Method}

\subsection{Research Model}

In this study, it was designed within the framework of a qualitative research design in order to examine the views of physical education teachers on distance education during the Covid-19 pandemic. Data were collected using the interview technique, one of the qualitative research methods. The interview technique is an effective data collection technique in terms of determining the perceptions, reactions and experiences of the participants (Yıldırım \& Şimşek, 2013).

\subsection{Research Participants}

Twenty physical education teachers, 8 female and 12 male, participated in this study. While forming the participants, volunteerism was taken as a basis and active working of teachers in secondary schools affiliated to the Ministry of National Education was accepted as a prerequisite. In the selection of the participants, the time they worked as a physical education teacher was taken as a criterion. In the teaching profession; Interviews were conducted with 5 teachers who worked for $0-5$ years, 5 teachers who worked for 6-10 years, 5 teachers who worked for 11-15 years and 5 teachers who worked for 16 years or more.

\subsubsection{Profiles of Participants}

Personal information of 20 physical education teachers participating in the study is included in Table 1. 
Table 1. Personal information of the participants

\begin{tabular}{cccc}
\hline Participants & Gender & Age & Experience Time \\
\hline P1 & W & 29 & $0-5$ years \\
P2 & W & 32 & $0-5$ years \\
P3 & M & 23 & $0-5$ years \\
P4 & M & 27 & $0-5$ years \\
P5 & M & 27 & $0-5$ years \\
P6 & W & 35 & 6-10 years \\
P7 & W & 38 & 6-10 years \\
P8 & M & 38 & $6-10$ years \\
P9 & M & 40 & $6-10$ years \\
P10 & M & 41 & $6-10$ years \\
P11 & W & 36 & $11-15$ years \\
P12 & W & 40 & $11-15$ years \\
P13 & M & 38 & $11-15$ years \\
P14 & M & 44 & $11-15$ years \\
P15 & M & 45 & $11-15$ years \\
P16 & W & 44 & 16 and over \\
P17 & W & 48 & 16 and over \\
P18 & M & 54 & 16 and over \\
P19 & M & 54 & 16 and over \\
P20 & M & 57 & 16 and over \\
\hline
\end{tabular}

\subsection{Data Collection Tools}

The data collected within the scope of the research were collected with the interview forms prepared by the researcher. The interview form consists of 4 questions aiming to determine the opinions of physical education teachers on distance education during the Covid-19 process. The interview questions were prepared for the purpose of the research, and they were finalized after being checked by two professors in the field of qualitative study.

The questions in the interview form;

1) Can you explain what distance education means to you, what do you understand when it comes to distance education?

2) Have you received any training related to distance education? How would you rate yourself on distance education?

3) Should physical education lessons be taught regularly during the Distance Education period? If you think it should or should not be processed, can you explain why?

4) How do you benefit from technology in the distance education process? What are the web tools you use most to create course content?

5) What do you think are the advantages and disadvantages of teaching physical education lessons in the distance education process?

\subsection{Data Collection and Analysis}

Interview technique and interview form within the scope of this technique were used to collect research data. While preparing the interview form, the relevant literature was scanned and appropriate questions were prepared by taking expert opinion. Necessary permissions were obtained for the study and approval was given by the scientific research and publication ethics committee of Düzce University (Number: E-78187535-640-29633). A pilot interview was conducted with a physical education teacher in order to ask the interview questions in the appropriate order. A face-to-face meeting was held by making appointments with the participants and recorded with a tape recorder. After the records were deciphered, the codings were made by two professors and researchers, who are experts in qualitative research. Descriptive analysis and content analysis methods were used in analyzing the data. Themes were formed by coding the data summarized from the interviews with descriptive analysis. Later, it was tried to establish conceptual links that serve to explain the relationship between the data obtained through content analysis and the goals (Büyüköztürk, 2013). The analysis was completed by interpreting the themes and 
codes in the findings section of the research. Within the scope of this research, reliability; It was calculated using the reliability formula suggested by Miles and Huberman (1994) and the reliability rate was found to be $87 \%$. It is used as another reliability criterion in direct quotations.

\section{Findings}

In this part of the research; The questions in the interview form were analyzed, and the theme, sub-themes and codings created over the data are shown.

Table 2. Definitions of physical education teachers regarding distance education expression

\begin{tabular}{cccc}
\hline THEME & SUB-THEME & CODING & $\mathrm{f}$ \\
\hline & & Virtual education & 8 \\
& & Independent education from time and space & 6 \\
Distance Learning & Technology supported education & 4 \\
& Definition & Asocial education & 2 \\
& & Education without feedback & 2 \\
& & Unequal opportunity education & 2 \\
\hline
\end{tabular}

When Table 2 is examined, it is seen that the opinions of physical education teachers on distance education are related to virtual education, time and place independent education and technology supported education. Some of the opinions of physical education teachers about distance education are as follows:

"A virtual educational environment where we come together with students using internet infrastructures"

"A technology supported education environment where information can be provided from anywhere and at any time"

"A form of education that allows us to continue the education process with the students we come together easily with the developing technology"

Table 3. Physical education teachers' views on whether or not they receive any education related to distance education

\begin{tabular}{|c|c|c|c|}
\hline THEME & SUB-THEME & CODING & $\mathrm{f}$ \\
\hline \multirow{9}{*}{ In-service training about the distance education program } & \multirow{2}{*}{ In-service training status } & Not participated & 15 \\
\hline & & Partıcıpated & 5 \\
\hline & \multirow{3}{*}{ Positive opinions } & The opportunity to learn about technology & 7 \\
\hline & & Developing new teaching strategies & 5 \\
\hline & & A different experience & 2 \\
\hline & \multirow{4}{*}{ Negative opinions } & Feeling of inadequacy & 2 \\
\hline & & It's not efficient & 1 \\
\hline & & Inability to keep up with technology & 1 \\
\hline & & Difficulty in creating course content & 1 \\
\hline
\end{tabular}

When Table 3 is examined, when examining the opinions of physical education teachers on whether or not to receive education about the distance education program during the Covid-19 pandemic, it is seen that they carry out the distance education process without any training. The opinions of physical education teachers about whether or not they receive education related to distance education are as follows:

"The process started without any training about distance education, then we learned by researching and examining over time"

"We had a hard time because we did not receive any training, it is very difficult to keep up with technology, we are trying to carry out the process by getting support from young teachers."

When Table 3 is examined, when we examine the positive opinions of physical education teachers about the distance education program during the Covid-19 pandemic period, it is seen that they have the opportunity to learn about technology intensively. The positive opinions of physical education teachers about distance education are as follows: 
"We have never used technology so intensely since physical education lessons are mostly conducted in face-to-face interaction, the distance education process was in a way a process where we learned how to use technology in lessons."

"We always prefer to teach the lessons face-to-face because physical education lessons are a lesson that we can get efficiency only when they are applied one-on-one, but this pandemic, although we do not want it, has forced us to learn remotely, how can we use technology in lessons to continue this process in the best way. we started to investigate. This process has been an opportunity for us to get to know the technology closely. "

When Table 3 is examined, when the negative opinions of physical education teachers about the distance education program are examined during the Covid-19 pandemic period, it is seen that most of the teachers feel inadequate. The negative opinions of physical education teachers about distance education are as follows:

"When the distance education started, I felt very foreign to this situation, I did not know what to do, students, we are novice, we are inexperienced, in this way I felt inadequate in front of the student."

"There were times when I felt insufficient in teaching when there was no feedback and very poor mutual interaction in distance education."

"We are so unfamiliar with technology that I realized this during the distance education process, I thought it was time to retire because you are inadequate and desperate when you cannot transfer your experience of years, and you question yourself when it is not useful."

Table 4. The opinions of the physical education teachers about the regular teaching of physical education lessons during the distance education period

\begin{tabular}{|c|c|c|c|}
\hline THEME & SUB-THEME & CODING & $\mathrm{f}$ \\
\hline \multirow{10}{*}{$\begin{array}{l}\text { Implementation of physical education lessons in } \\
\text { distance education }\end{array}$} & Courses processing & Must be a lesson & 15 \\
\hline & status & May not be a lesson & 5 \\
\hline & & Supports physical and spiritual development & 7 \\
\hline & & Provides mobility & 5 \\
\hline & Positive opinions & $\begin{array}{c}\text { Physical education lesson is just as important as } \\
\text { other lessons. }\end{array}$ & 2 \\
\hline & & Increases motivation & 1 \\
\hline & & Low efficiency & 2 \\
\hline & Negative opinions & $\begin{array}{l}\text { There is a risk of injury as there is no one-to-one } \\
\text { control }\end{array}$ & 1 \\
\hline & & No way to practice & 1 \\
\hline & & Problems in material procurement & 1 \\
\hline
\end{tabular}

When Table 4 is examined, it is seen that there is a greater opinion that the lessons should be taught when the views of physical education teachers on the status of distance education and physical education lessons in the Covid-19 pandemic period are examined. The opinions of the physical education teachers about the teaching of the courses related to distance education are as follows:

"Physical education lessons should be taught because children who are inactive at home during the pandemic period need this lesson where they can release their energy and motivate them to other lessons."

"Physical education lesson is as important as the other courses in the curriculum, so it is very important for the physical and mental development of children to have this lesson in distance education as in face-to-face education."

When Table 4 is examined, when we examine the positive opinions about the teaching of physical education lessons in the distance education process during the Covid-19 period, it is seen that the answers of the lessons support physical and mental development and increase the mobility of children. The positive opinions of the physical education teachers about the teaching of the courses related to distance education are as follows;

"In the process of distance education, physical education lessons should be taught regularly, as physical education classes provide content that supports physical development and physical health of children during the pandemic period, and psychological exercise provides positive effects on children and allows them to relax in a depressed period." 
"Due to the Covid-19 pandemic, children remained at home and had a sedentary period in front of the computer. In this process, the effects of physical negativity caused by inactivity are somewhat reduced with physical education classes and encourage children to move. "

"The physical and mental needs of the students, who were affected most by the pandemic and had to stay at home, can be met to some extent through physical education lessons, and physical development of children is supported by providing mobility thanks to the exercises and physical activities applied."

When Table 4 is examined, when we examine the negative opinions about the teaching of physical education lessons in the distance education process during the Covid-19 period, there is a risk of injury because the efficiency of the lessons is low and there is no one-to-one control. It seems that the answers are used more intensely. The negative opinions of the physical education teachers about the teaching of distance education courses are as follows:

"The inability of the student and the teacher to communicate in the same environment is very important in terms of the quality and permanence of education. Especially in physical education lessons, this is more important than other lessons. At this point, the distance education system is inadequate and inefficient. "

"As physical education teachers, we, as physical education teachers, practice the skills we will develop at a distance by showing them live in front of the screen or we want the children to practice it by telling them from the videos we have prepared before. We find it difficult to increase the motivation to participate in the lessons, and when the movements are not done correctly, the feedback becomes difficult for every student in the crowded classrooms. This situation brings with it both the failure to teach the movement as desired and the disability of the student with a wrong move. Certainly the lessons are less efficient than face-to-face education. "

"While the efficiency we get in the lesson develops a very low motor skill, doing this in an environment where there is no one-to-one interaction with the child does not replace face-to-face education in terms of gain."

"Although distance education uses technology to close the distance and bring students and us together, controlling the student is not particularly close control in the production of a physical movement, so the movement is wrong and wrong, so there is a risk of injury.

Table 5. The opinions of physical education teachers about the benefits of technology in distance education and the web tools they use most

\begin{tabular}{|c|c|c|c|}
\hline THEME & SUB-THEME & CODING & $\mathrm{f}$ \\
\hline \multirow{8}{*}{ Technology in distance education } & \multirow{4}{*}{ Taking advantage of technology } & Online course creation & 9 \\
\hline & & Creating a virtual classroom & 5 \\
\hline & & Videos & 4 \\
\hline & & Creating bitmoji & 1 \\
\hline & \multirow{4}{*}{ Web tools } & EBA & 9 \\
\hline & & Canva & 7 \\
\hline & & Genial.ly & 3 \\
\hline & & Mentimeter & 1 \\
\hline
\end{tabular}

When Table 5 is examined, when examining how they benefited from technology in physical education lessons in the distance education process in the Covid-19 period; It is seen that the participants mostly expressed their opinions on creating live lessons or virtual classrooms. The opinions of physical education teachers about using technology in distance education courses are as follows:

"For physical education lessons in distance education, I mostly use technology to create a vibrant classroom. By creating a live class, I get the opportunity to come together with students and teach the lessons as if they were in the same environment."

"I create my own virtual classroom thanks to web tools. There, I create bitmoji in my own character and convey the content of the course to the students at the beginning of the lesson as a preliminary information."

When Table 5 is examined, when the web tools they use most in physical education lessons in the distance education process in the Covid-19 period are examined; It is seen that the participants use EBA and Canva extensively. The opinions of physical education teachers about the web tools that are mostly used in distance education lessons are as follows: 
"The web tool I use the most for physical education lessons is EBA (Education Information Network) created by the Ministry of National Education. Thanks to this web tool, we continue my lessons and do the exercises at home with my students."

"I usually use EBA (Education Information Network) while preparing my lessons, sometimes there is a web tool called canva.com while creating a virtual classroom. From there, I create my own class with the features I want and teach my lesson."

"We can create a classroom through Canva, and I even try to create an interaction between myself and the student by creating a bitmoji that reflects my own physical characteristics in this classroom. With a bitmoji that looks like me in front of them, they both have information about what we will do that day in that lesson, and they also have an idea about me."

Table 6. Physical education teachers' opinions about the advantages and disadvantages of teaching physical education lessons in the distance education process

\begin{tabular}{|c|c|c|c|}
\hline THEME & SUB-THEME & CODING & $\mathrm{f}$ \\
\hline \multirow{14}{*}{ Advantage } & \multirow{2}{*}{ Time independence } & Watching the lesson at any time & 7 \\
\hline & & Prepare lecture videos in advance & 5 \\
\hline & \multirow{2}{*}{ Spatial independence } & Access to the lesson from your environment & 8 \\
\hline & & Bringing people from different venues together & 3 \\
\hline & \multirow{3}{*}{ Saving time } & Transportation & 15 \\
\hline & & Absence of undesirable situations outside of the classroom & 6 \\
\hline & & Few factors to distract the issue & 4 \\
\hline & \multirow{2}{*}{ Opportunity for development } & Learning to take advantage of technology & 11 \\
\hline & & Learning web tools & 9 \\
\hline & \multirow{5}{*}{ Learning environment functionality } & Reduce stress and anxiety & 7 \\
\hline & & Not feeling the fear of not being able to do & 6 \\
\hline & & Lack of peer pressure & 3 \\
\hline & & Ability to repeat the movement as many times & 3 \\
\hline & & Meeting learning needs in safe environments & 2 \\
\hline \multirow{16}{*}{ Disadvantage } & \multirow{2}{*}{ Inequality of opportunity } & Difficulty accessing the internet and computer & 17 \\
\hline & & Difficulty in creating/procuring course material & 6 \\
\hline & \multirow{6}{*}{ Learning environment shortcomings } & Not providing one-to-one assistance in movement teaching & 18 \\
\hline & & Difficulty in maintaining class dominance & 14 \\
\hline & & Physical structure of the home environment & 13 \\
\hline & & Low motivation for active participation & 7 \\
\hline & & Absenteeism & 6 \\
\hline & & Being unprepared for the lesson & 2 \\
\hline & \multirow{2}{*}{ Feedback gaps } & No immediate feedback on the wrong action & 11 \\
\hline & & Student's reluctance to ask questions & 9 \\
\hline & \multirow{2}{*}{ Risks } & Injury & 5 \\
\hline & & Incorrect/incorrect/incomplete learning of motor skill & 3 \\
\hline & \multirow{3}{*}{ Lack of socialization } & Inability to interact & 17 \\
\hline & & Inability to create emotional bonds & 8 \\
\hline & & Difficulty communicating & 6 \\
\hline & Evaluation issues & Inability to evaluate & 13 \\
\hline
\end{tabular}

When Table 6 is examined, it is seen that in the Covid-19 period, physical education teachers mostly expressed their views on the advantages of distance education, regardless of time and place. The opinions of physical education teachers about the advantages of distance education are as follows:

"The most important advantage is that students have the opportunity to attend classes in any place and place they want regardless of the classroom, and they have the opportunity to watch and practice these lessons over and over again whenever they want. They can re-open their home exercise practices at any time and apply them at home."

"In distance education, the student had the opportunity to use or access various resources via EBA whenever he 
wanted. This situation improved the use of technology skills of both students and also us teachers, and provided ease of accessing information whenever and wherever it wanted."

"The opportunity of practicing the movements as they wish in a comfortable environment like home in this lesson, which includes physical exercise practices, both eliminated the thinking structures of students as what my friends would think if I do wrong, and reduced their anxiety and increased motivation."

When Table 6 is examined, it is seen that the views of physical education teachers about the disadvantages of distance education in the Covid-19 period are mostly in the direction of inequality of opportunity and learning environment.

The opinions of physical education teachers about the disadvantages of distance education are as follows:

"Every student may not have a computer or internet access opportunity to continue their education in this process, and this situation creates inequalities about receiving education within the scope of the principle of equal opportunity of education."

"Students with limited financial means have trouble attending classes."

"When physical education lessons want to gain special skills in sports branches other than simple exercise movements at home, a lesson that needs a lot of various materials and materials, students do not have the opportunity to access these materials in a home environment, so there are problems during the lessons."

"We are trying to create materials to be used in the lessons from the materials found in the house. This causes a waste of time."

\section{Discussion}

Covid-19 are also pandemic is almost no studies conducted on the operation of physical education classes in Turkey. Within the scope of this study, the opinions of physical education teachers about distance education were examined and a discussion was made with the literature in this section.

The opinions of physical education teachers about what distance education means for physical education teachers were examined and coded under the sub-theme of definition. It is seen that the views mostly define distance education as "virtual education" and "education independent from time and place". When the studies conducted within this scope are examined, "home education" (Özdoğan \& Berkant, 2000); "Online teaching environment" (Almanthari et al., 2020); "E-learning" (Üstün et al., 2020); It is seen that definitions such as "education in computer and internet environment" (Ekiz, 2020) are used.

When the opinions of physical education teachers about whether or not they receive any education related to distance education and how they evaluate themselves in this process, it is seen that the majority of the participants have not received any training related to distance education before and they feel inadequate in this process, and the part of the process that is perceived as positive for them is mostly It is seen that they consider using technology as an opportunity to learn. When other studies are examined; In the study he conducted in Ekiz (2020), he examined teachers' evaluations in terms of receiving education about distance education before and, if they did, in terms of efficiency and inefficiency; It has been observed that the number of teachers who receive training is higher than those who do not, but those who consider it inefficient are higher than those who give the efficient answer. Flack et al. (2020) stated in their study that the lack of self-confidence of teachers in using technology in the distance education process causes problems, while another study argues that teachers are unprepared for the transition to distance education (Chiemeke \& Imafidor, 2020). In another study examining teachers 'readiness for distance education, they evaluated teachers' readiness and self-confidence as a medium level (Üstün et al., 2020). Within the scope of this study, when teachers were suddenly faced with distance education due to the pandemic without being prepared and without training, supported by the studies carried out, it may have caused them to feel inadequate due to lack of readiness and self-confidence. Because Kurtoğlu and Seferoğlu (2013) stated in their study that although teachers have positive attitudes towards technology, they feel themselves inadequate and incomplete, and they need professional development related to technology. However, in another study, it was observed that Norwegian and American teachers were willing to use and learn technology (online environments), which they managed the process well, even though they did not have distance education experience before the pandemic, thus overcoming the problems (Gudmundsdottir \& Hathaway, 2020). When we examine the theme of positive perception as another outcome of this study, teachers evaluated this process as an opportunity to learn to use technology in lessons and revealed that they strive to overcome the problems.

When the opinions of the physical education teachers regarding the situation that physical education lessons should not be taught regularly during the distance education period were examined, it was seen that the majority of 
the participants participating in the study expressed their opinion that physical education lessons should also be taught during the pandemic process. The positive opinions they reported about the processing are that students who are inactive during the Covid-19 pandemic, especially during this period, need physical education lessons more for their physical and mental development. When the negative opinions about the teaching of the lessons are examined, it is seen that the lessons are not efficient. When we look at the attitude of other countries in the case of teaching physical education lessons during this pandemic period, which negatively affected all countries of the world at the same rate; In the study conducted by EUPEA (2020 act; Özcan \& Saraç, 2020); It is observed that in $41 \%$ of the 41 EUPEA member countries, schools continue the distance education process and physical education classes are also included in the process in these countries. In $38.5 \%$ of the member countries, it is seen that schools continue face-to-face education, but physical education lessons are taught within the framework of the restrictions applied. In $15.4 \%$ of the member countries, face-to-face education continues, but physical education lessons are not taught. Within the scope of the same study, it is seen that $75 \%$ of the countries do not reduce the duration of physical education lessons, but $25 \%$ of them do. As an example, in Italy, where there is no restriction on lesson hours, with the decision to continue education in schools remotely, physical education teachers were supported with various materials and received seminars and trainings to enable them to continue their lessons effectively. At the same time, it is observed that students are guided to act through social media campaigns. For Turkey distance education process through EB by immediate operation of the ministry of education, although providing access to resources for many courses physical education teachers of these resources how it is seen that the need to support training in can handle and how efficient course they will use (Ozcan and Sarac, 2020). Examining how physical education teachers make use of technology in the distance education process and their views on the web tools they use most in creating course content, it is seen that the most used web tool when they use technology to create live lessons is EBA, which was created by the Turkish Ministry of National Education. Rachmadtullah et al. (2020) emphasized in their study that teachers' efficient use of technology online during the pandemic process has a significant contribution to success in learning. He drew attention to the fact that the student's interest and motivation decreased in the online environment, so it was emphasized that it was important for teachers to use the databases well and to have the necessary equipment to enrich the course content in this sense. The importance of remote teaching of physical education lessons for students who are away from school, friends and social life during the pandemic period has been emphasized and it has been stated that the applications to be made in these lessons are important for students (Tison et al., 2020). When the interviews conducted within the scope of this study were examined, it was found that teachers who use web tools efficiently increased their desire to participate in the lessons, as they were able to keep children's interest and motivation higher.

When the opinions of physical education teachers about the advantages and disadvantages of teaching physical education lessons in the distance education process are examined; views on the advantages of distance education are gathered on the subthemes of time independence, space independence, time saving, development opportunity, learning environment functionality, and the opinions regarding its disadvantages are on the subthemes of inequality of opportunity, lack of learning environment, lack of feedback, risk, lack of socialization and evaluation problems. seems to be concentrated. When the studies are examined; He states that distance education is an opportunity and its greatest advantage is to meet the educational need (Almaghaslah \& Alsayari, 2020). In his study, Kaden (2020) states that the biggest advantage of learning support during the COVID-19 pandemic is seen as distance education. Chan et al. (2007) in their study in another pandemic period; They demonstrated that distance education, which enables the sharing of information during pandemic periods, is a great advantage in meeting the necessary education need. In another study they conducted on university students, Andoh et al. (2020) revealed that the most intense view of students about distance education is to use technological facilities more effectively. In another study expressing the same opinion, it is stated that the aspect of distance education, which is considered as the advantage of technology, improves skills in the use of technology and raises awareness about the importance of technology in education (De Paepe et al., 2018). Results of the studied studies; The opinions on the advantages of this study show similarities with the coding of learning how to benefit from the technology coded under the sub-theme of development opportunity and using web tools in distance education. When the studies are examined, it is seen that the most distinctive feature of distance education is that it provides education independent of time and place (DeNeui \& Dodge; 2006). Alpaslan (2020) in their study; They stated that it has advantages such as being practical and flexible towards the advantages of distance education, providing diversity in access to information and being independent of time and place. Similarly, Fidan (2020) mentions the advantage of independence from time in their study. Yolcu (2020) states in his study that distance education is one of the important advantages of spatial independence. When we look at the subthemes of independence from time and independence from space, it is seen that there is a similarity. The most important advantage of distance education is that it provides time and space convenience, as well as it saves time by eliminating the time of arrival and departure 
to school (Horspol \& Lange, 2012). In this finding; It is seen that this study shows similarities with the other sub-themes of saving time and transportation, which is its sub-coding. It is possible to express distance education as education that provides ease of access (Koç, 2020). Horspol and Lange (2012) in their study; They evaluated the increase in the quality of communication and the ease of learning in terms of environment thanks to online applications as an advantage. Within the scope of this study, it is seen that the learning environment functionality finding, which is a sub-theme, is similar. When the literature is examined, it can be said that the findings obtained from the studies and the findings obtained as a result of this study show consistency.

When we examine the sub-themes formed from the disadvantages of distance education, which are frequently mentioned in the study; Inequality of opportunity, lack of learning environment, feedback deficiencies, risks, lack of socialization, evaluation problems. When the related research results are examined, it is seen that similar results are obtained. Distance education does not provide equal opportunities for every student, and students living in rural areas appear to be more disadvantaged in this regard (Ramos-Morcillo et al., 2020). This view is similar to the inequality of opportunity sub-theme of the study. The codes of this inequality of opportunity theme emerge as difficulty in accessing the Internet and computers, and difficulty in obtaining course material. In this sense, it is seen that students with insufficient financial status have problems with computer or internet access. Or, since there is no access to materials and materials provided by the state in the school environment, the students try to provide the materials used in the lessons with the facilities at their homes, and in this case, it again puts some groups in a disadvantaged position. In another study, it was reported that students had problems in communicating in distance education, as well as technical problems caused by internet or computers during education (Keskin \& Özer-Kaya, 2020). Likewise, DePaepe et al. (2018) reported that the major disadvantage of distance education is technical support problems. Another sub-theme created within the scope of this study; It is the lack of socialization and the codings made within this scope are seen to be the inability to interact, establish an emotional bond, and communicate. Horspol and Lange (2012) stated that students' perceptions of their disadvantages in the distance education process are seen as inadequate socialization opportunities. In another study, Koç (2020) revealed that the disadvantages of distance education are seen as the lack of interaction between the instructor and the student, students not attending regular classes, and technical problems. Serçemeli and Kurnaz (2020) stated in their study on students that one of the disadvantages of distance education is seen as the lack of interaction between the instructor and the student. These findings are similar to the study.

\section{Conclusion and Recommendations}

Within the scope of this research, it was aimed to review the distance education process from the perspective of physical education teachers during the Covid-19 pandemic process. Within the scope of this purpose, some advantages and disadvantages of distance education have emerged. Within the scope of the study, the disadvantages caused by distance education were evaluated and recommendations were made. It is revealed that the continuation of physical education lessons during this pandemic process is seen as important in terms of protecting both physical and mental health of students who are worn out with excess during this period. In this process, it is seen that physical education teachers who have just gotten acquainted with distance education have training deficiencies about distance education and how to use technology efficiently. In this sense, providing training for teachers is considered important in terms of both continuing the process more efficiently and reducing the anxiety experienced by teachers. Distance education should be individualized in order to be a fully supportive education, and some courses should be redesigned in order to teach more efficient lessons based on practice, especially physical education. Kaden (2020) emphasizes that distance education can be supportive for many students, but must be carefully designed and individualized in order not to deepen social divisions. Ensuring equality of opportunity to support the right of every student to receive education under the same conditions is another important issue. Y1lmaz-İnce et al. (2020) in their research; He stated that students' computer and internet access facilities affect their views on distance education. In this sense, it is important for every student to have access to these opportunities in terms of providing education and the proper execution of the evaluation process. Because evaluation cannot be done without measurement and it does not give accurate results in an evaluation without a healthy teaching process, and this issue is one of the main disadvantages that should be addressed systematically (Sar1, 2020; Can, 2020). Another major disadvantage of distance education is the lack of socialization. By examining the studies conducted in this sense (Gewin, 2020; Attri, 2012) how to ensure active participation of the student in the lesson, how to create in-class interaction, how to provide information and feedback between teachers and students, to provide effective communication, to identify students in distress and how to support them. It is thought that creating joint reports on issues as required will be beneficial in reducing the problems of this process. Planning and standardizing the course contents and materials to be used at the beginning of the distance education process, having a common plan and program on how to teach physical education lessons 
will also relieve the system and increase efficiency.

Within the scope of this study, the following suggestions can be made for the distance teaching of physical education lessons.

- When the difficulties of physical education teachers in having distance applications are seen in the distance education process, in-service trainings for teachers can be planned.

- Physical education teachers can be taught how to benefit from various web tools that enrich course content, and these tools can be accessed.

- By standardizing the contents of physical education lessons, exercise programs that are easy to apply at home and without risk can be created.

- Material design studies can be made on how to create materials (balls, mattresses, etc.) that physical education teachers should use in lessons with their students in the home environment, and these materials can be prepared at the beginning of the education process.

- Assessment of physical education lessons can be tied to a standard again, by developing distance education measurement and evaluation methods for physical education lessons, in-service training can be provided on this subject.

- Improvements can be made towards the disadvantages that arise in educational environments by carrying out academic studies for the teaching of physical education lessons in distance education.

\section{References}

Al Lily, A. E., Ismail, A. F., Abunasser, F. M., \& Alqahtani, R. H. A. (2020). Distance education as a response to pandemics: Coronavirus and Arab culture. Technology in Society.

Ally, M. (2019). Competency profile of the digital and online teacher in future education. International Review of Research in Open and Distributed Learning, 20(2). https://doi.org/10.19173/irrodl.v20i2.4206

Almaghaslah, D., \& Alsayari, A. (2020). The effects of the 2019 novel coronavirus disease (COVID-19) outbreak on academic staff members: A case study of a Pharmacy School in Saudi Arabia. Risk Management and Healthcare Policy, 13, 795-802. https://doi.org/10.2147/RMHP.S260918

Almanthari, A., Maulina, S., \& Bruce, S. (2020). Secondary school mathematics teachers' views on e-learning implementation barriers during the COVID-19 pandemic: The case of Indonesia. Eurasia Journal of Mathematics, Science and Technology Education, 16(7).

Alpaslan, M. (2020). Öğretim üyelerinin özel yeteneklilerin eğitiminde uzaktan eğitimin kullanımına yönelik görüşleri. Açıköğretim Uygulamaları ve Araştırmaları Dergisi, 6(1), 126-147.

Andoh, R. P. K., Appiah, R., \& Agyei, P. M. (2020). Postgraduate distance education in University of Cape Coast, Ghana: Students' perspectives. International Review of Research in Open and Distributed Learning, 21(2), 118-135. https://doi.org/10.19173/irrodl.v21i2.4589

Attr1, A. K. (2012). Distance education: problems and solutions. International Journal of Behavioral Social and Movement Sciences, 1(4), 42-58.

Bawane, J., \& Spector, J. (2009). Prioritization of online instructor roles: Implications for competency-based $\begin{array}{llll}\text { teacher education programs. } & \text { Distance 383-397. }\end{array}$ https://doi.org/10.1080/01587910903236536

Büyüköztürk, Ş., Kılıç Çakmak, E., Akgün, Ö. E., Karadeniz, Ş., \& Demirel, F. (2013). Bilimsel araştırma yöntemleri. Ankara: Pegem Akademi.

Can, E. (2020). Coronavirüs (Covid-19) pandemisi ve pedagojik yansımaları: Türkiye'de açık ve uzaktan eğitim uygulamaları. Açıöğretim Uygulamaları ve Araştırmaları Dergisi, 6(2), 11-53.

Chan, S. S., So, W. K., Wong, D. C., Lee, A. C., \& Tiwari, A. (2007). Improving older adults' knowledge and practice of preventive measures through a telephone health education during the SARS epidemic in Hong Kong: a pilot study. International Journal of Nursing Studies, 244(7), 1120-1127. https://doi.org/10.1016/j.ijnurstu.2006.04.019

Chiemeke, S., \& Imafidor, O. M. (2020). Web-based learning in periods of crisis: Reflections on the impact of Covid-19. International Journal of Computer Science \& Information Technology (IJCSIT), 12(3), 33-46. https://doi.org/10.5121/ijcsit.2020.12303 
De Paepe, L., Zhu, C., \& DePryck, K. (2018). Drop-out, retention, satisfaction and attainment of online learners of Dutch in adult education. International Journal on E-Learning, 17(3), 303-323.

Deneu1, D., \& Dodge, T. (2006). Asynchronous Learning Networks and Student Outcomes: The Utility of Online Learning Components in Hybrid Courses. Journal of Instructional Psychology, 33(4), 256-259.

Ekiz, M. A. (2020). Beden Eğitimi ve Spor Yüksekokulu Öğrencilerinin Karantina Dönemindeki Uzaktan Eğitim İle İlgili Görüşleri (Nitel Bir Araştirma). Spor ve Rekreasyon Araştırmaları Dergisi, 2(Özel Sayı 1), 1-13.

Farmer, H. M., \& Ramsdale, J. (2016). Teaching competencies for the online environment. Canadian Journal of Learning and Technology, 42(3), 1-17.

Fidalgo, P., Thormann, J., Kulyk, O., \& Lencastre, J. A. (2020). Students' perceptions on distance education: A multinational study. International Journal of Educational Technology in Higher Education. https://doi.org/10.1186/s41239-020-00194-2

Fidan, M. (2020). Covid-19 belirsizliğinde eğitim: İlkokulda zorunlu uzaktan eğitime ilişkin öğretmen görüşleri. Uşak Üniversitesi Eğitim Araştırmaları Dergisi, 6(2), 24-43. https://doi.org/10.29065/usakead.736643

Flack, C. B., Walker, L., Bickerstaff, A., \& Margetts, C. (2020). Socioeconomic disparities in Australian schooling during the COVID-19 pandemic. Melbourne, Australia: Pivot Professional Learning.

Gewin, V. (2020). Covid-19 bekletilirken öğretimi çevrimiçi taşımak için beş ipucu. Doğa, 580, 295-296.

Gudmundsdottir, G. B., \& Hathaway, D. M. (2020). We always make it work: Teachers' agency in the time of crisis. Journal of Technology and Teacher Education, 28(2), 239-250.

Hellewell, J., Abbott, S., Gimma, A., Bosse, N. I., Jarvis, C. I., Russell, T. W., ... \& Eggo, R. M. (2020). Feasibility of controlling COVID-19 outbreaks by isolation of cases and contacts. The Lancet Global Health, 8(4), e488-e496. https://doi.org/10.1016/S2214-109X(20)30074-7

Horspool, A., \& Lange, C. (2012). Applying the scholarship of teaching and learning: Student perceptions, behaviours and success online and face-to-face. Assessment \& Evaluation in Higher Education, 37(1), 73-88. https://doi.org/10.1080/02602938.2010.496532

Kaden, U. (2020). Covid-19 school closure-related changes to the professional life of a k-12 teacher. Education Sciences, 10(6), 165. https://doi.org/10.3390/educsci10060165

Keskin, M., \& Özer-Kaya, D. (2020). Covıd-19 sürecinde öğrencilerin web tabanlı uzaktan eğitime yönelik geri bildirimlerinin değerlendirilmesi. İzmir Kâtip Çelebi Üniversitesi Sağllk Bilimleri Fakültesi Dergisi, 5(2), 59-67.

Koç, E. (2020). An evaluation of distance learning in higher education through the eyes of course instructors. Akdeniz Üniversitesi Eğitim Fakültesi Dergisi, 3(1), 25-39.

Kurtoğlu, M., \& Seferoğlu, S. S. (2013). Öğretmenlerin teknoloji kullanımı ile ilgili Türkiye kaynaklı dergilerde yayımlanmış makalelerin incelenmesi. Journal of Instructional Technologies \& Teacher Education, 2(3), $1-10$.

Miles, M. B., \& Huberman, A. M. (1994). Qualitive data analysis. İnternational educational and professional publisher. Thousand Oaks London New Delhi: SAGE.

Millî Eğitim Bakanlığı (MEB). (2020). Bakan Selçuk, koronavirüs'e karşı eğitim alanında alınan tedbirleri açıkladı. Retrieved from https://www.meb.gov.tr/bakan-selcuk-koronaviruse-karsi-egitimalaninda-alinantedbirleri-acikladi/haber/20497/tr

Özcan, B., \& Saraç, L. (2020). Covıd-19 Pandemisi Sürecinde Öğretmen Çevrimiçi Uzaktan Eğitim Rol Ve Yeterlikleri: Beden Eğitimi Öğretmenleri Örneği. Milli Eğitim Dergisi, 49(1), 459-475.

Özdoğan, A. Ç., \& Berkant, H. G. (2020). Covıd-19 Pandemi Dönemindeki Uzaktan Eğitime İlişkin Paydaş Görüşlerinin İncelenmesi. Milli Eğitim Dergisi, 49(1), 13-43.

Rachmadtullah, R., Aliyyah, R. R., Samsudin, A., Syaodih, E., Nurtanto, M., \& Tambunan, A. R. S. (2020). The perceptions of primary school teachers of online learning during the COVID-19 pandemic period: A case study in Indonesia. Journal of Ethnic and Cultural Studies, 7(2), 90-109. https://doi.org/10.29333/ejecs/388

Ramos-Morcillo A. J, Leal-Costa, C., Moral-García J. E \& Ruzafa-Martínez, M. (2020). Experiences of nursing students during the abrupt change from face-to-face to e-learning education during the first month of confinement due to Covid-19 in Spain. International Journal of Environmental Research and Public Health, 17(15), 5519. https://doi.org/10.3390/ijerph17155519 
Sarı, H. (2020). Evde kal döneminde uzaktan eğitim: Ölçme ve değerlendirmeyi neden karantinaya almamalıyız? Uluslararası Eğitim Araştırmacıları Dergisi, 3(1), 121-128.

Serçemeli, M., \& Kurnaz, E. (2020). Covid-19 pandemi döneminde öğrencilerin uzaktan eğitim ve uzaktan muhasebe eğitimine yönelik bakış açıları üzerine bir araştırma. Uluslararası Sosyal Bilimler Akademik Araştırmalar Dergisi, 4(1), 40-53.

Tison, G. H., Avram, R., Kuhar, P., Abreau, S., Marcus, G. M., Pletcher, M. J., \& Olgin, J. E. (2020). Worldwide effect of COVID-19 on physical activity: A descriptive study. Annals of Internal Medicine, 173(9), 767-770.

United Nations Educational, Scientific and Cultural Organization (UNESCO). (2020a). Education: From disruption to recovery. Retrieved from https://en.unesco.org/covid19/educationresponse

United Nations Educational, Scientific and Cultural Organization (UNESCO). (2020b). Covıd-19 crisis and curriculum: Sustaining quality outcomes in the context of remote learning. Retrieved from https://unesdoc.unesco.org/ark:/48223/pf0000373273

United Nations Educational, Scientific and Cultural Organization (UNESCO). (2020c). Supporting teachers and education personnel during times of crisis. Retrieved from https://unesdoc.unesco.org/ark:/48223/pf0000373338

Üstün, A. B., Karaoğlan Yılmaz, F. G., \& Yılmaz, R. (2020). Öğretmenler e-öğrenmeye hazır mı? Öğretmenlerin e-öğrenmeye yönelik hazır bulunuşluklarının incelenmesi üzerine bir araştırma. Ahmet Keleşoğlu Eğitim Fakültesi Dergisi, 2(1), 54-69.

Uşun, S. (2006). Uzaktan eğitim. Ankara: Nobel Yayıncılık.

Watts, L. (2016). Synchronous and asynchronous communication in distance learning: A review of the literature. Quarterly Review of Distance Education, 17(1), 23-32.

World Health Organization (WHO). (2020). Retrieved from https://www.who.int/news/item/27-04-2020-who-timeline-Covid-19

Yıldırım, A., \& Şimşek, H. (2013). Sosyal bilimlerde nitel araştırma yöntemleri (9. Baskı). Ankara: Seçkin Yayıncilik.

Yılmaz-İnce, E., Kabul, A., \& Diler, İ. (2020). Distance education in higher education in the Covid-19 pandemic process: A case of Isparta Applied Sciences University. International Journal of Technology in Education and Science (IJTES), 4(4), 343-351. https://doi.org/10.46328/ijtes.v4i4.112

Yıp, P. S. F., \& Chau, P. H. (2020). Physical distancing and emotional closeness amidst Covid-19. Crisis, 41(3), 153-155. https://doi.org/10.1027/0227-5910/a000710

Yolcu, H. (2020). Koronavirüs (Covid-19) pandemi sürecinde sınıf öğretmeni adaylarının uzaktan eğitim deneyimleri. Açıöğretim Uygulamaları ve Araştırmaları Dergisi, 6(4), 237-250.

\section{Copyrights}

Copyright for this article is retained by the author(s), with first publication rights granted to the journal.

This is an open-access article distributed under the terms and conditions of the Creative Commons Attribution license (http://creativecommons.org/licenses/by/4.0/). 